
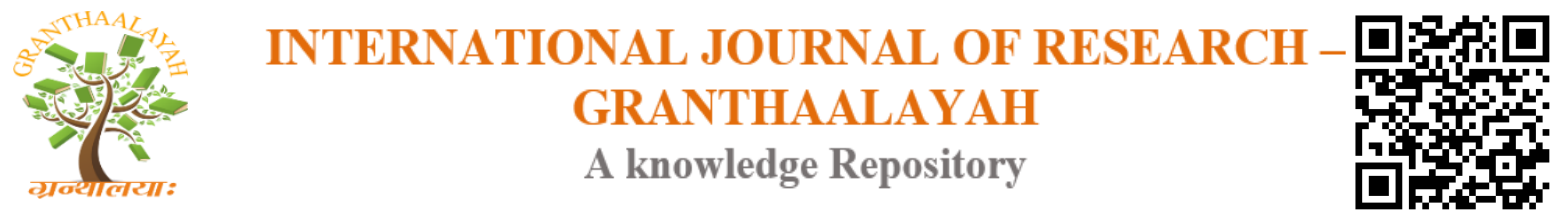

Management

\title{
IDENTIFICATION OF CONSTRAINTS IN PROJECT SCHEDULE MANAGEMENT
}

\author{
Anjay Kumar Mishra ${ }^{1}$, Kailash Kumar Moktan ${ }^{2}$ \\ ${ }^{1}$ Visiting Faculty, Management Science, Shanker Dev Campus, Tribhuvan University, \\ Kathmandu, Nepal \\ ${ }^{2}$ Engineer, Dolidar
}

\begin{abstract}
Theory of Constraints (TOC) is new concept of project management. Every project has some constraints. This study explores the constraints to improve the project performance dealing with time constraint with a case of Sankosh-Tipling Road project and Bhimdhunga-Lamidanda Road Project of Dhading District.

Questionnaire survey, Project report analysis, Key informant interview and case studies were the methods used for the data collection and content analysis, S-Curve and interim payment assessment were done to process the data.

The major constraint among several other constraints in Bhimdhunga-Lamidanda Road project, legal constraint which is restriction of District Coordination Committee (DCC) to collect gravel and boulders from river and quarry sites was found as major constraint in the project. Constraint has affected with time extension for total 309 days with progress of only 34.76\% till 13 june, 2017. Thus, this study has assumed that project could be completed within previously proposed deadline if different counter measures which have been suggested with consideration of TOC.
\end{abstract}

Keywords: Rural Road Projects; S-Curve; Delays; Critical Chain.

Cite This Article: Anjay Kumar Mishra, and Kailash Kumar Moktan. (2019). "IDENTIFICATION OF CONSTRAINTS IN PROJECT SCHEDULE MANAGEMENT." International Journal of Research - Granthaalayah, 7(2), 18-35. https://doi.org/10.29121/granthaalayah.v7.i2.2019.990.

\section{Introduction}

In early days of project management, the projects were of short duration and environment has much more stable. The modern-day projects like infrastructure projects have complex site nature; time consuming, unbalanced cash flows, complex contractual agreements (Mishra and Mallik, 2017). Sufficient human resources are available with Nepalese construction firms (Mishra, 2018). Value management need to be implemented (Mishra, 2019). Thus, projects have single or multiple constraints restricting the project progress from timely completion. A Constraint is a condition, agency or force that impedes progress on objective or goal (Lau\& Kong, 2006). Constraints should be identified and described in as much as possible during the early stage of a project. So that 
awareness on them and their potential impact can be managed. This includes understanding the dynamics of project and how different constraints interrelate. Constraints are anything that either restricts the action of the project team or dictates the action of the project team. Constraints put project team in a box. Project manager have to manage several project constraints, which sometimes requires creativity. Like most disciplines, project management can often be as much art as it is a science. As much as creative it is process- driven. Constraints in construction projects limit their achievement of high performance. Identifying the constraints provides the practical steps for making organizational decisions in which constraints exist. If constraints are better understood at the outset, it is believed that better performance can be assumed.

With the increasing complexity of the construction projects, proper planning and control of project activities now represent key issues in the construction scheduling management. Generally, one objective of the construction schedule planning and control is to make successful on-time completion of each activity in project. Theory of Constraints (TOC) can be applied to projects to improve performance. Furthermore, the TOC approach focuses on successful on-time completion of the entire project. According to TOC, the main constraint in any project is the time taken for completion of the critical activities. Therefore, emphasis is laid on completing activities in the critical path without wasting any time. In 1997, Goldratt introduce a new approach for project management, Critical Chain (Jan \& Ho, 2006). The new concept is widely known and applied in practice. Critical Chain in a project is defined as the longest sequence of activities from several different paths, connected by activities performed by common resources. The safety time in a critical chain is removed from individual activities and is utilized to create the project buffer. The project is to be guarded against delays by providing time buffers. Hence, cutting safety time from critical activities eliminate the major cause of the wastage, thereby removing the constraints. These buffers provide the necessary cushions to individual activities to enable them to accomplish the final goal of completing critical chain in the least possible time.

In context of Nepal, Construction projects are facing challenges regarding several constraints and ultimately results into delay. In case of road construction project, these constraining factors are frequently encountered so that on-time project completion is greatly affected by constraints. To resolve such problem, there's a possibility of applying the new concept in the project management i.e. Critical Chain Project Management (CCPM). It deals with the time and resource constraint while scheduling the project activities and ensures the timely completion of project improving the project performance.

\section{Research Objectives}

The overall objective of this study was to identify the constraints in the specified road construction project working environment and review the possibility of Critical Chain Project Management (CCPM) approach for effective scheduling.

\section{Literature Review}

\section{Theory of Constraints (TOC)}

The Theory of Constraints is a concept describing methodology for identifying the most important limiting factor (i.e. Constraint) that stands in the way of achieving a goal and then systematically 
improving the constraint until it is no longer the limiting factor (Lau \& Kong, 2006). Dr. EliyahuGoldaratt conceived the Theory of Constraint (TOC) and introduced it to a wide audience through his bestselling 1984 Novel, "The Goal". Since then, TOC has continued to evolve and develop and today it is a significant factor within the world of management best practices. One of the appealing characteristics of the Theory of Constraints is that it inherently prioritizes improvement activities. The top priority is always the current constraints. In environments where there is an urgent need to improve, TOC offers a highly focused methodology for creating rapid improvement. The core concept of the Theory of Constraints is that; every process has a single constraint and that total process throughput can only be improved (Jacob \& William, 2003). A very important corollary to this is that spending time optimizing non-constraints will not provide significant benefits; only improvements to the constraint will further the goal (achieving more profit). Thus, TOC seeks to provide precise and sustained focus on improving the current constraint until it no longer limits throughput, at which point the focus moves to the next constraint. The underlying power of TOC flows from its ability to generate a tremendously strong focus towards a single goal (profit) and to removing the principal impediment (The Constraint) to achieving more of that goal. In fact, Goldratt considers focus to be the essence of TOC. TOC is a common-sense way to enhance system improvement. Any system usually at least has a constraint likes that weakest part of the system. The system only becomes stronger until it can improve the strength of the weakest part.

It has been suggested that TOC can be applied to project management. Construction projects are intricate, time-consuming undertakings. The construction projects need a good management to achieve the satisfied result including functional satisfaction, aesthetic satisfaction, completion on time, and completion within budget, value for money and health and safety. (Walker, 1989) defines the construction management as "The planning, control and coordination of a project from conception to completion (including commissioning) on behalf of a client. It is concerned with identification of the clients' objectives in terms of utility, function, quality, time and cost, and the establishment of relationships between resources. The integrating, monitoring and control of contributors to the project and their output and the evaluation and selection of alternatives in pursuit of the clients' satisfaction are the fundamental aspects of construction project management. The project definition process is significant if it offers the opportunity for the clients and the teams to identify the constraints and project constraints have to be considered when formulating the project strategy (Chua et. al, 2003). Quantifying the assessment of the actual constraining effect on project objectives and the procurement process, Theory of Constraints will be adopted in the construction context because project development in this respect resembles a production process in which productivity is affected by various constraints. Goldratt propose a five-step process to achieve continual improvement and to get the most of overcome.

\section{The Five Focusing Steps}

The Theory of Constraints provides a specific methodology for identifying and eliminating constraints, referred to as five focusing steps (Vorne_Industry, 2011).

- Identify: Identify the current constraint (The single part of the process that limits the rate at which the goal is achieved).

- Exploit: Make quick improvements to the throughput of the constraint using existing resources (i.e. make the most of what you have). 
- Subordinate: Review all other activities in the process to ensure that they are aligned with and truly support the needs of constraints.

- Elevate: If constraint still exists (i.e it has not moved), consider what further actions can be taken to eliminate it from being the constraint. Normally actions are continued at this step until the constraint has been "broken" (until it has moved somewhere else). In some cases, capital investment may be required.

- Repeat: The five focusing steps are a continuous improvement cycle, therefore; once a constraint should immediately be addressed. This step is a reminder to never become complacent - aggressively improve the current constraint and then immediately move on to the next constraint.

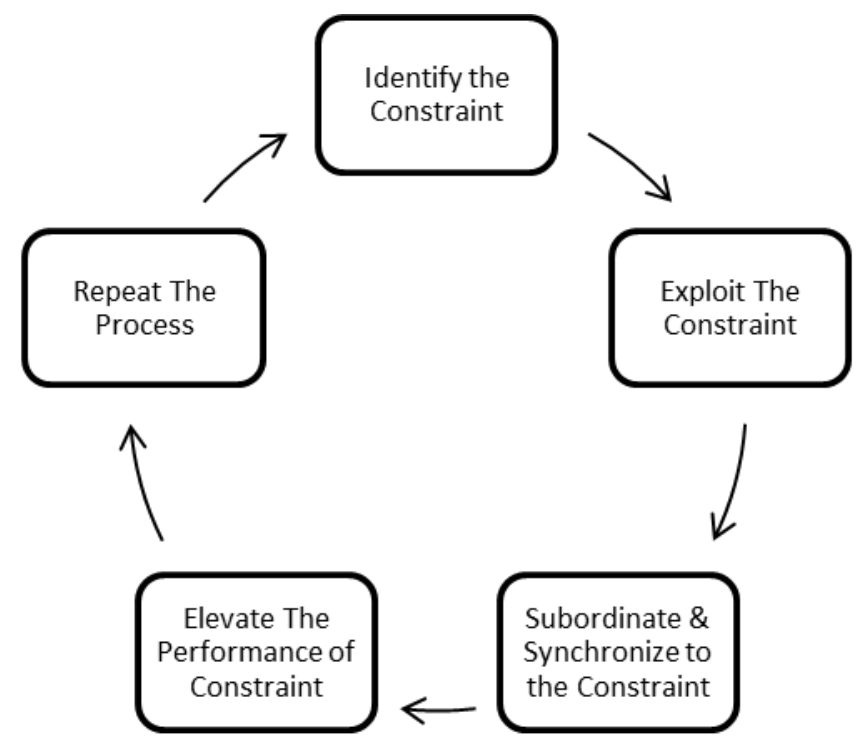

(Vorne_Industry, 2011)

Figure 2.1: TOC-Five Focusing Steps

\section{Theory of Constraints Applications}

The processes defined in Goldratt's Theory of constraints have been applied to the areas of manufacturing, distribution, marketing, sales and finance, and project management (Jackson \&Gelhorn, 1994). Here are some lists of examples of applications and solution related to this theory.

- Manufacturing: Within manufacturing operations management, the solution seeks to pull materials through the system, rather than push them into the system. This prevents bottlenecking while resource exploitation.

- Project Management: This is sometimes called Critical Chain Project Management (CCPM), which is a method of planning and managing projects that puts more emphasis on the resources used to execute project tasks. The solution will tend to keep resources levelly loaded but will require them to be flexible in their scheduling.

- Distribution: The solution for supply chain constraints is to move a replenishment model, rather than a forecast model. The replenishment model would represent at inventory that is able to meet customer demand while being regularly replenished by some manufacturing facility or other source. 
- Marketing and sales: While originally focused on manufacturing and logistics Goldratt's Theory of Constraints (TOC) has expanded into areas of marketing, sales and finance. The application here is surprisingly similar to that of manufacturing and is sometimes called customer manufacturing. The solution is to avoid market bottlenecking while ensuring maximized sales and marketing resources.

- Finance: The solution for finance and accounting is to apply holistic thinking to the finance application. This has also been "Throughput accounting" and suggests that one examine the impact of investments and operational changes in terms of the impact on the throughput of the business.

\section{Improvement of Manufacturing Process Through TOC}

Theory of Constraint (TOC) is widely used in manufacturing industry for production process and its improvement. TOC is best known for its application to production scheduling. TOC application is much fruitful to overcome the high inventories problem, long lead time problem, poor customer service, poor productivity, too much overtime, too much expediting, priorities constantly shifting and frequent material and part shortages. The Theory of Constraints (TOC) is a systematic and iterative approach to management that emphasizes adapting business practices in order to best cope with limitations or constraints that stands in the way of key objectives (Watson et. al 2007). The goal of TOC is to maximize the efficiency of a process selectively at the most critical points and thereby maximizing profitability, quality or other corporate objectives. TOC assumes the number of subsystem. If each of these subsystems are optimized individually, overall company performance may actually be considered disappointing because such an approach doesn't take into account how the sub systems interact and what their collective limitations are in the production process. Instead, the idea is to optimize the system as a whole, even if it means certain nonessential components aren't optimally efficient. The company must identify its core problems (or Constraints) first. These constraints can involve; product quality, product cost, product engineering effectiveness, materials procurement, production planning and control and marketing. These constraints are most likely to directly affect the company's profitability and cash flow, such a constraint on profitability and cash flow serves as the platform for the TOC management philosophy.

Throughput in manufacturing is the rate at which a system generates profit through sales after reduction for material costs, commissions, and distribution costs. Using TOC, objective of manufacturing is to maximize throughput while minimizing operating expenses (Bushong \& Talbott, 1999). For manufacturing concerns, the constraining factor is often but not always the time available on a certain machine or process. Once constraining factors has been identified, the next step is to determine the throughput per unit of the constraining factor. The key to maximizing profit is to concentrate on selling and producing products that provide the highest throughput per unit of constraining factor. Implementation of TOC is often difficult because it may require a complete change in the way the company operates. If the company compensates the sales force based on commission of sales, there is an incentive to sell products with the highest sales price. Uses of TOC as a management philosophy is a dynamic process, once the constraining factor has been identified, management should examine whether the constraining factor can be increased. If this is possible, some other factor may become constraint and the analysis should be revised based upon the new circumstances. 
Another principle Lean Manufacturing combining with TOC, the TOC can serve as a highly effective mechanism for prioritizing improvement projects; while Lean Manufacturing can provide a rich tool box of improvement techniques (Vorne_industry, 2011). The result-manufacturing effectiveness is significantly increased by eliminating waste from the parts of the system that are the largest constraints on opportunity and profitability. A result is published by the Victoria University of Wellingotn (Victoria_University, 2016) determined that on average the results achieved by implementing the TOC are:- $69 \%$ mean lead-time reduction,- $60 \%$ mean due date performance improvement,- $50 \%$ mean inventories reduction and - $68 \%$ mean throughput increase.

\section{Critical Chain Project Management (CCPM)}

Critical Chain Project Management (CCPM) is a methodology for planning, executing and managing projects in single and multi-project environments. CCPM was developed by Dr. EliyahuGoldratt and was first introduced to the market in his Theory of Constraints (TOC) book "Critical Chain", 1997. It was developed in response to many projects being dogged by poor performance manifested in longer than expected durations, frequently missed deadlines, increased costs in excess of budget and substantially less deliverables than originally promised. The Critical Chain is the longest chain and determines the lead time of the project. Basically, the method describes how to combat stretching out task durations estimates, caused by avoiding task uncertainty. Buffer management is introduced in order to control uncertainties with respect to project timing. Resource managers tend to increase lead time estimates since they are expected to give reliable information.

TOC has been applied to project management in order to address the typical issues experienced by project managers that led to project delays and failures. The resulting approach, described by (Goldratt, 1997) as the 'Critical Chain' method for the project management, challenges the flawed assumption that the only way to achieve better performance is through good local performance throughout the system. Thus, he proposed CCPM as a systematic approach which advocated focusing on the longest chain activities. CCPM seeks to change project behavior, which encourages reporting early completion of activities and elimination of multitasking. Goldratt's TOC analysis showed that these are all effects of a core underlying cause: failure to manage uncertainty. Therefore, CCPM, as an application of TOC to project management, defines a project as a chain of activities with duration as its core constraints. According to the Goldratt "an application makes assumptions (sometimes hidden assumptions) about the environment and it should not be expected the application to work environments for which its assumptions are not valid." Therefore, assumptions underpinning CCPM need to be supported by evidence within the environment in which it is applied if such application is to be successful.

The major assumption of CCPM concerns the definition of the core constraint. As stated above, CCPM suggests the longest chain of activities is the core constraint in all projects. CCPM also assumes that certain behaviors will occur, such as deliberate padding (padding estimates in order to avoid being late on commitments); Murphy's Law (if anything can go wrong, it will); Parkinson's Law (work extends to fill the time allowed); and Student's syndrome (the type of procrastination students are prone to when they are assigned a project or are facing a test) (Goldratt, 1997). CCPM also suggests that uncertainty is the major obstacles and core cause of undesirable effects in projects. However, (Raz et al, 2003) argue that other obstacles, such as external pressure, internal policies and distorting estimates; are as important. 
The main conceptual elements of CCPM are presented in the following section in the context of planning, execution and continuous improvement. It is distinctive differences with conventional project management are also presented.

\section{Project Planning}

- CCPM takes account of resources as well as precedence dependencies in determining the project durations. This is termed the Critical Chain. In figure 2.3 the Critical Path would be denoted by activities 1-3-4, whereas in Critical Chain it is denoted by 1-3-2-

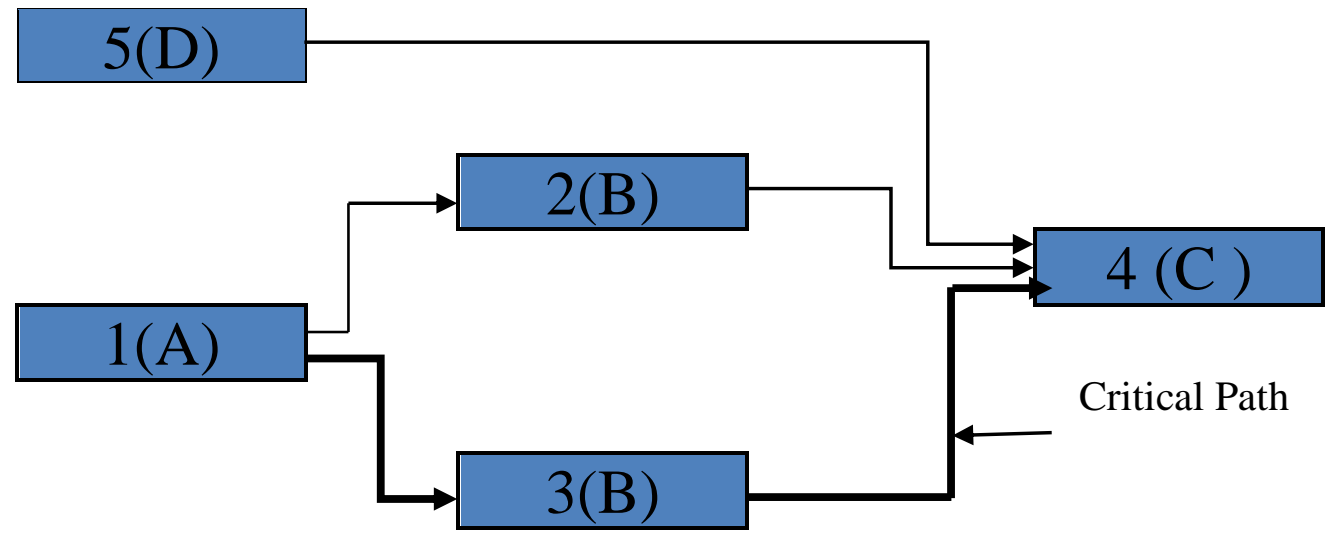

Resources: A, B, C, D

Figure 2.2: Simple Network Diagram

Source: (Stratton, 2010)

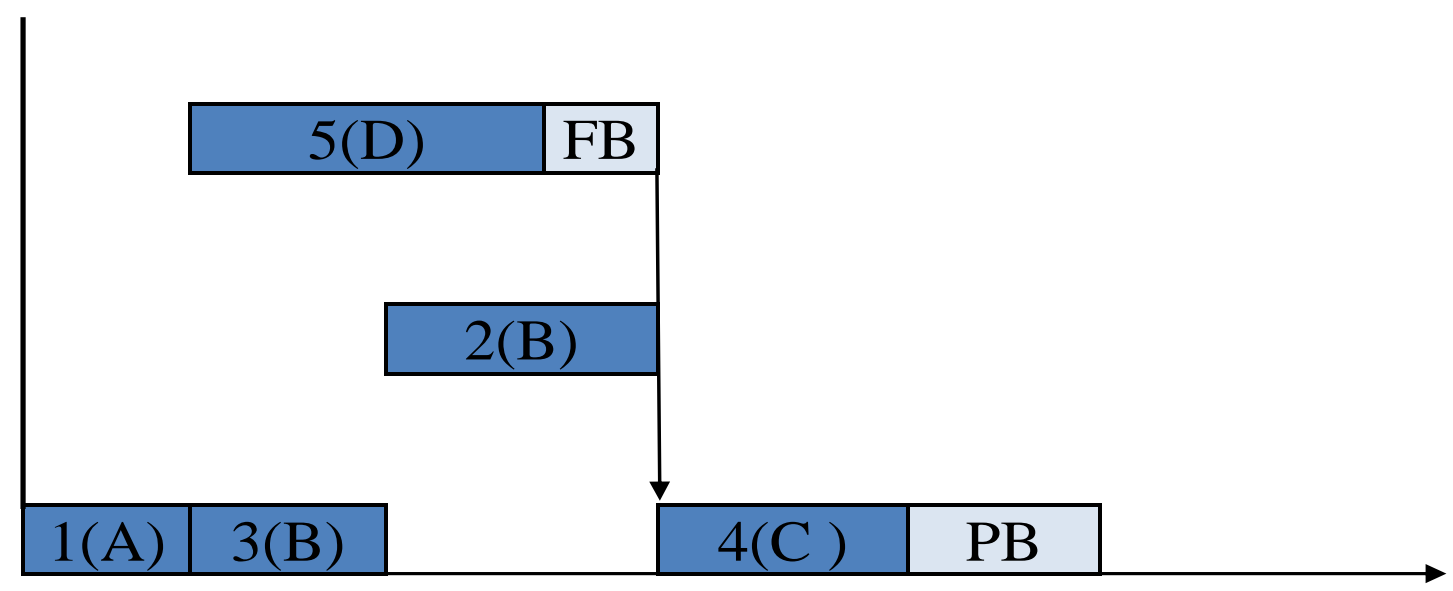

Figure 2.3: Network diagram and Critical Chain Schedule showing buffers.

FB: Feeding Buffer, PB: Project Buffer

Source: (Stratton, 2010)

- 4 due to common resource B. In such cases, the Critical Chain is shown to be longer than the Critical Path and all four activities need to be managed accordingly.

- CCPM introduces the concept of project and feeder time buffer accommodate the effective management buffer time that is commonly wasted at the end of the project to protect the Critical Chain. Thus, such buffers enable aggregation of the buffer time as well as better 
control, enabling both shorter and more controllable lead times. In establishing those buffers, the proposed start point is to halve existing activity times and put half of the remainder into aggregated buffer. Therefore, the buffer is equal to a third of the activity and buffer combination.

- When planning in a multi-project environment, CCPM advocates staggering the release of projects around a designated resource that acts as a drum. This is used to ensure flow and avoid too many open projects that result in excessive multitasking and missed due dates.

\section{Project Execution and continuous improvement}

- Tasks completion reporting

It is common practice for activity times to be reported in terms of work done, an economic measure that is often only formally reported weekly or even monthly. With CCPM the remaining time to complete the activity is reported on a much more frequent basis ideally daily.

- Provide visibility of upcoming tasks

As there are no intermediate tasks dates in the planning system the tasks-time-remaining data provides advanced notice of upcoming tasks (this has previously been referred to as a resource buffer).

- Current and upcoming tasks are monitored in line with priorities to ensure tasks are effectively progressing. Project can be monitored by monitoring buffer usage. Therefore, a project buffer status chart (also called 'Fever chart') being used for tracking and alerting the progress.

\section{Methodology}

\section{Sampling and Population}

Study was conducted based on purposive sampling method with $100 \%$ of targeted sampling i.e. Project Implementation Members 21 persons.

\section{Collection of Data and Information}

The stakeholders of the project were Donors, GoN, Contractors, Consultants, Building Groups, Beneficiaries, local people and etc. Both qualitative and quantitative data were collected and used in the study. Similarly, both primary and secondary types of data were collected and used in the study.

Information/Data obtained from respondents were analyzed with the help of simple statistical tools and techniques. The collected and analyzed data have been presented in simple forms using charts, graphs and tables.

\section{Primary Data}

The main techniques of primary data collection are:

\section{1) Field Visit \& Observation}

The road project (study area) was visited. The work activities, its nature, it's complexity, work force, speed of work, geographical condition, location, social issues were observed. Informal meetings were conducted with stakeholders at site. Photographs of the site were also collected. 


\section{2) Questionnaire Survey}

A simple set of questionnaireswas also supplied to collect list of possible constraints in the project, causes and factor for the time and resource constraints, reliability of TOC variables. Interview/Questionnaire wasalso focused on the problems on traditional approach for scheduling of project. Questionnaire regarding status of projects, possible constraining factors, major work processes, availability of resources, scheduling technique, governing factors for time overrun and perception on student syndrome, Parkinson's law, multitasking was asked to the project team members (21 Nos) and also interview was conducted to know the perception on construction project management.

\section{3) Desk Studies}

Desk study was conducted to collect stakeholder's perception, understanding and view regarding the project management aspects of the road project. Desk study was carried out by close consultation with district project team consultant and client to understand the work flow methodology, characteristics of work, location, socio-political \& Environmental situation of the work.

\section{4) Case Studies}

Case study regarding work schedule was carefully examined and analyzed by collecting the progress reports, documents, interim payment certificates, time extension documents, legal decision documents. Two different cases as shown in figure 3.1 were examined for the study, one for Sankosh-Tipling Road and another for Bhimdhunga-Lamidanda Road. For Sankosh-Tipling, work schedule submitted by contractor was examined for its analysis and generalized for network diagrams to fit within the Critical Chain Project Management (CCPM) approach and compared with the actual progress status. Then, CCPM with buffer managements were applied to overcome the time constraint. The basic five steps of TOC were considered for CCPM application by identifying the constraints through interview, questionnaire and content analysis, exploitation through buffer sizing and its placement, subordination through movement of non-constraint resources toward the critical chain activities and elevating the system constraints through addition of extra resources required in the critical activities. The time buffers which are project buffer and feeding buffers, were created by summing up of half of each activity duration from feeding and critical chain. Project buffer and feeding buffers were inserted at end of critical chain and feeding chains respectively. Then, Buffer penetration scenario was interpreted to know how the buffers are consumed as the activities are implemented and resulted the views regarding the project completion period whether it could be completed earlier as much as project buffer's size or within the pre-specified date of completion. For Bhimdhunga-Lamidanda, Project, constraints were identified through the questionnaire, key informant interview and content analysis, and basic steps of TOC were applied suggesting the counter measures with exploitation of resources, subordination of resources and elevating the system performance. Counter measures to overcome the constraint identified was supposed that it could ensure for completion of project within intended date of completion. These cases were discussed indepth information regarding the construction constraints, effective schedule and planning, monitoring and control of project for timely completion of the project. 


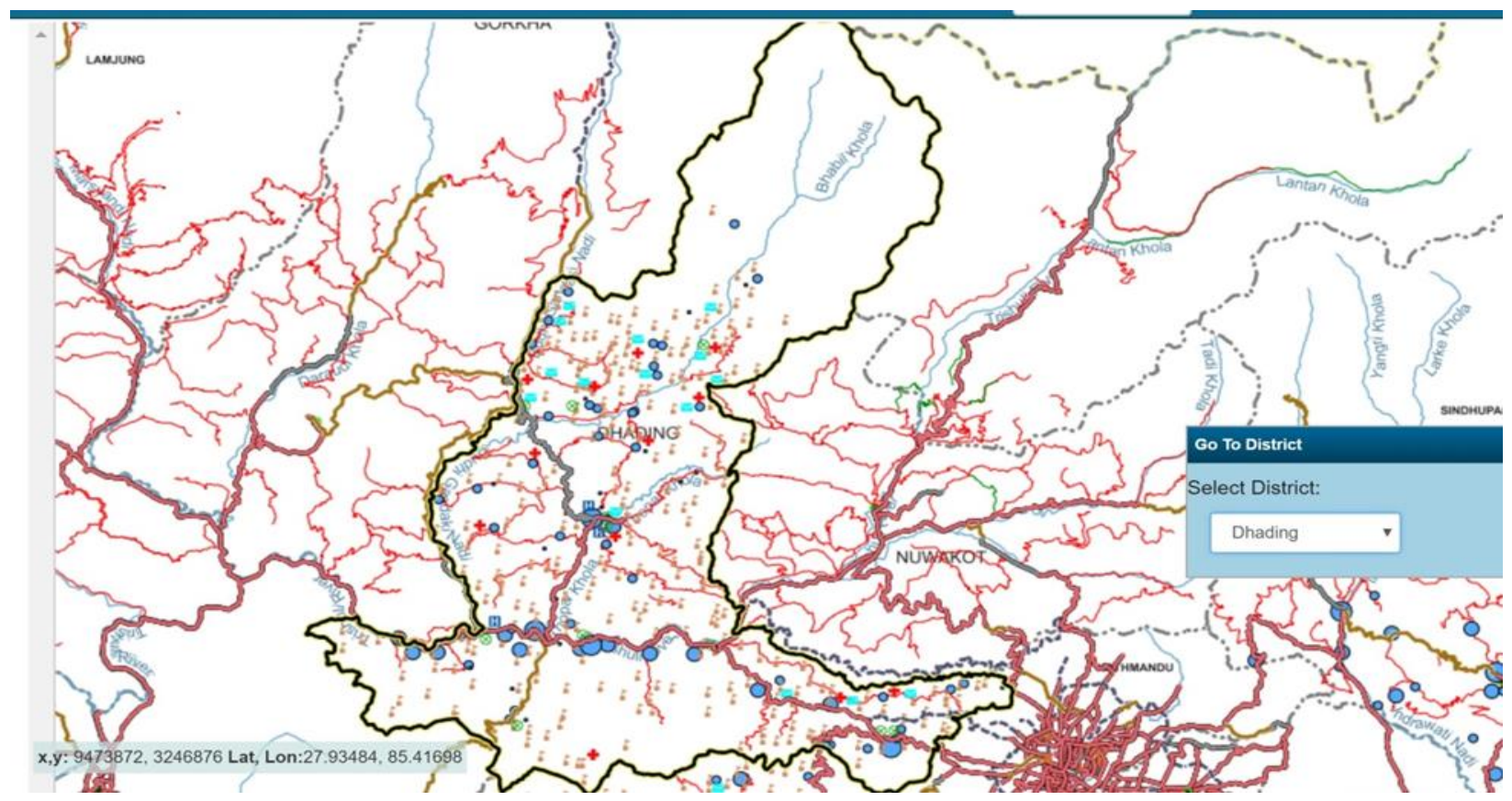

Figure 3.1: Location Map and Alignment of Roads

\section{Secondary Data}

The secondary data were collected from the following Sources:

- Literature Review

- Documents and Reports of SNRTP program unit and DTOs.

- Publications of various Project management related researchers.

- Other published and unpublished literature, reports and journals.

- Internet and websites.

- Research Books.

\section{Processing of Data}

In order to identify the major constraint in the proposed schedule in the case project, this study analyses the detail progress chart of the project and constraints which are impeding the progress of the activities. For this analysis, collection of the proposed scheduled bar chart, progress reports, interim payment certificates were collected. As well as, the field visit, interview and discussion were made with the consultants, the contractors and the employers and their representatives.

\section{Content Analysis}

Contents of project reports were taken for analyzing the project progresses and overall status of the project. Bar-chart submitted by contractor were collected and analyzed whether it could fit or not within Critical Chain Project Management (CCPM). Performance variables like timeline, work progress, expenditure documents were collected and interpreted in tabular form as well as in Scurve diagram to understand the status of the project. Extension of project, variable for project time extension were also considered for understanding the delay of project. Last date of study was considered based on the last date of latest interim payment released to the contractor. Internal organizational strength like resource capacity, alternative solutions, future capacity requirements were discussed and analyzed for removing the time constraint. 


\section{Processing and Utilization of Data}

All the relevant data were processed and analyzed to determine the constraints in project, constraint in the scheduling, to determine the critical chain in the work schedule submitted, and to apply the TOC and CCPM approach to effective scheduling of project. After collection of necessary data, opinion and information of the selected respondents, the data and information were complied, analyzed and interpreted by the network diagram, S-curve and bar chart of schedule with management of time and resources.

\section{Reporting and Presentation}

The interpretation of the proposed scheduling was presented in the form of bar chart and network diagram, S-curve chart,effective scheduling of the construction project using CCPM approach werealso presented in the form of network diagram with buffer management of time and resources, as well as, the practical interpretation regarding monitoring and controlling of project schedule were shown in figure. Different counter measures were suggested based on TOC to remove systematically the time constraint with help of internal resources as well as the external resources. The work activities of the work schedule and optimized time schedule were carefully accessed, analyzed and interpreted for further study of the CCPM not only in context of the rural road construction but also for overall construction project management in Nepal.

\section{Results and Discussions}

\section{Constraints of Selected Project}

Two different studies were conducted for two different roads. The constraints were identified based on the field observation, desk studies, interview/questionnaire and content analysis of project reports and documents.

\section{Identification of Constraint "Sankosh-Tipling Road Dhading"}

This study was carried out for applying the Critical Chain Project Management (CCPM). Though, this project is under implementation, so rescheduling was proposed for improving the performance of project.

A question regarding the major constraints existing in the project schedule was asked to 21 (100\% of sample by purposive sampling) project implementation members from District Unit, Project Management Unit (PMU), and Central Project Coordination Unit (CPCU). And the major constraint causing delayis presented in table 4.1.

Table 4.1: Response on Rank of Constraint

\begin{tabular}{|l|l|l|l|l|l|}
\cline { 2 - 7 } \multicolumn{1}{c|}{} & \multicolumn{5}{l|}{ Rank } \\
\hline Constraint & 1 & 2 & 3 & 4 & 5 \\
\hline Economic Constraint & 0 & 0 & 3 & 13 & 5 \\
\hline Legal Constraint & 0 & 0 & 1 & 6 & 14 \\
\hline Environmental Constraint & 0 & 2 & 17 & 1 & 0 \\
\hline Technical Constraints & 15 & 5 & 1 & 0 & 0 \\
\hline Social Constraints & 6 & 14 & 1 & 0 & 0 \\
\hline
\end{tabular}


This question was designed to rank the potential impact of the constraint in the schedule proposed. So, Order of rank was in sequence of 1,2,3,4 and 5, where 1 is the highest impact.

$71 \%$ of respondent ranked ' 1 ' to technical constraint, $67 \%$ of respondent ranked ' 2 ' to social constraint, $85 \%$ respondent ranked 3 to environmental constraint and $62 \%$ respondent ranked ' 4 ' to Economic constraint and $67 \%$ respondent ranked ' 5 ' to legal constraint. Referring to table 4.1, it can be analyzed that, Technical constraint has the highest potential to cause the delay of activities. By the case study, interview and analysis of project report, it can be concluded that Technical constraint in case of Detail Project Report (DPR) preparation had encountered the problem. DPR was prepared 5 years back by other agency (Road Department branch office), and the same DPR was processed for the tendering of the construction. Later, when joint construction survey team was mobilized, the survey control points were missing, road profile, cross section were also changed because of several small construction activities have been implemented during 5 years. So, Mobilization and joint survey works had taken more time than originally proposed. Though this activity lies in the critical path of the project, it has affected the overall duration of the project.

Similarly, other constraints like Social and Environmental constraint have higher order (2 and 3) of impact. The details of the change in contract amount due to change in design and survey report is summarized in Table 4.2 based on project documents.

Table 4.2: Change in Contract Amount due to Change in Design

\begin{tabular}{|l|l|l|l|}
\hline \multirow{2}{*}{ Description } & As per contract & $\begin{array}{l}\text { As per } \\
\text { construction } \\
\text { Survey }\end{array}$ & \multirow{2}{*}{ \% Change } \\
\cline { 2 - 3 } & Amount (NRs) & Amount (NRs) & \multicolumn{1}{|l}{} \\
\cline { 2 - 3 } General & 2250000 & 2250000 & $0 \%$ \\
\hline Site Clearance & 23600 & 41500 & $-76 \%$ \\
\hline Earthworks & 26019562.19 & 23364764.28 & $10 \%$ \\
\hline Sub-base, Base and Shoulders & 36406493.16 & 38766805.34 & $-6 \%$ \\
\hline Stone Masonry for Structures & 73036953.9 & 93631637.75 & $-28 \%$ \\
\hline Gabion Masonry Work for Structures & 43850250 & 53113500 & $-21 \%$ \\
\hline Formwork and Surface Finish for Structures & 2666860 & 2766750 & $-4 \%$ \\
\hline Plain and Reinforced Cement Concrete for Structures & 52469980 & 51805078.33 & $1 \%$ \\
\hline Bio-engineering Work & & & \\
\hline Miscellaneous Work & 1161000 & 1161000 & $0 \%$ \\
\hline Dayworks & 8797000 & 9645000 & $-10 \%$ \\
\hline Grand Total (NRs.) & 415500 & 441500 & $-6 \%$ \\
\hline & $247,097,199.25$ & $276,987,535.70$ & $-12 \%$ \\
\hline
\end{tabular}

\section{Proposed Schedule of the Project}

The original schedule of project is proposed using Bar (Gantt) chart by contractor. Due to inherent limitation of bar chart not showing task dependencies, critical path and sequence of activities, original bar chart is converted into network diagram (i.e. Critical Path Method) for indicating the critical path. Then, the Critical path method is generalized for application of Critical Chain Project Management (CCPM). The schedule of the project contains the different activities such as Mobilization and joint construction survey, General works and site clearance, Earthworks, Stone masonry works, Gabion Structure works, Concrete works, Sub-Base, Base and shoulder works, 
Miscellaneous works, Bio Engineering works and finally handover to client. It has contract period of 15 months from Agreement signed date 22nd September, 2016 to 21st December, 2017, Actual Site possession issued by Client is 15 th day from date of signing. But, it can be seen that, Contractor has started the Joint survey from October 2 nd week and contractor had intended to complete within November last week of 2017.

The following figure 4.1 showing proposed schedule, which can be analyzed that, there is a critical path A-B-G-J having duration of 51 weeks. Activities are Mobilization and joint survey, General works and site clearance, sub-base, base and shoulder works and finally handover to client.

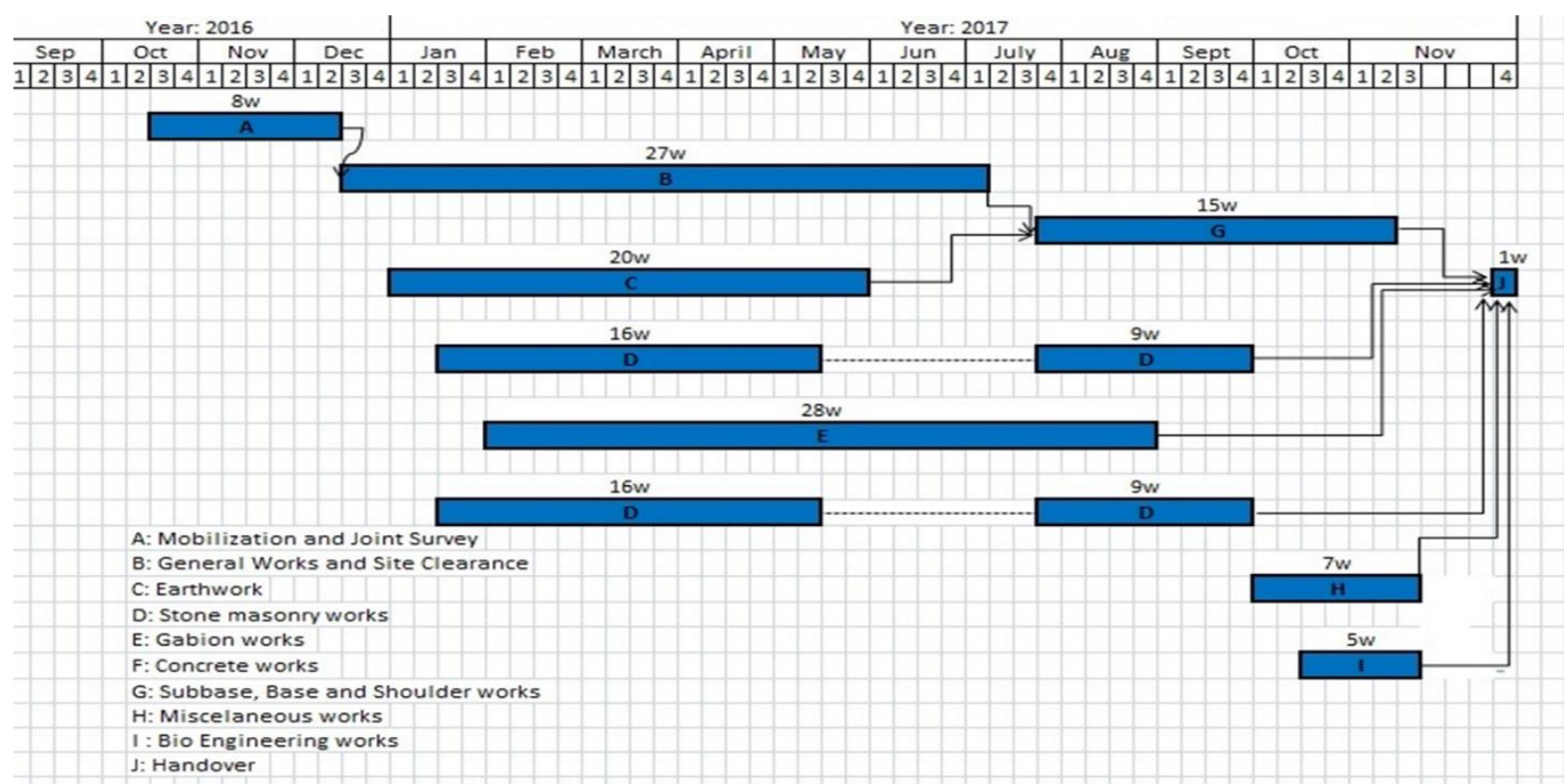

Figure 4.1: Schedule submitted by Contractor at time of Agreement (Sankosh-Tipling)

Table 4.3: Actual Progress of Project (Sankosh-Tipling) till 21 Dec, 2017

\begin{tabular}{|c|c|c|c|c|c|c|c|c|c|c|c|c|}
\hline \multirow[b]{2}{*}{$\begin{array}{l}\mathbf{S} \\
\dot{\mathrm{N}}\end{array}$} & \multirow[b]{2}{*}{$\begin{array}{l}\text { Description of } \\
\text { works }\end{array}$} & \multicolumn{2}{|c|}{ 8th feb 2017} & \multicolumn{2}{|c|}{$\begin{array}{ll}22 & \text { April, } \\
2017 & \end{array}$} & \multicolumn{2}{|c|}{ 4th july, 2017} & \multicolumn{2}{|c|}{ 1st sept, 2017} & \multicolumn{2}{|c|}{21 Dec, 2017} & \multirow{2}{*}{$\begin{array}{l}\text { Item } \\
\text { wise } \\
\text { Cumul } \\
\text { ative } \\
\% \text { Com } \\
\text { pletion }\end{array}$} \\
\hline & & $\begin{array}{l}\text { Amo } \\
\text { unt } \\
\text { NRs. }\end{array}$ & $\begin{array}{l}\text { \% com } \\
\text { pleted }\end{array}$ & $\begin{array}{l}\text { Amo } \\
\text { unt }\end{array}$ & $\begin{array}{l}\% \\
\text { Com } \\
\text { plete } \\
\text { d } \\
\end{array}$ & $\begin{array}{l}\text { Amo } \\
\text { unt }\end{array}$ & $\begin{array}{l}\text { \% Co } \\
\text { mplete } \\
\text { d }\end{array}$ & $\begin{array}{l}\text { Amo } \\
\text { unt }\end{array}$ & $\begin{array}{l}\% \mathrm{Co} \\
\text { mplete } \\
\text { d }\end{array}$ & $\begin{array}{l}\text { Amo } \\
\text { unt }\end{array}$ & $\begin{array}{l}\% \text { Co } \\
\text { mplete } \\
\text { d }\end{array}$ & \\
\hline 1 & $\begin{array}{l}\text { General works } \\
\text { and site clearance }\end{array}$ & $\begin{array}{l}12533 \\
00.00\end{array}$ & $\begin{array}{l}55.12 \\
\%\end{array}$ & $\begin{array}{l}1000 \\
00\end{array}$ & $\begin{array}{l}4.40 \\
\%\end{array}$ & $\begin{array}{l}5750 \\
0\end{array}$ & $2.53 \%$ & $\begin{array}{l}5200 \\
0\end{array}$ & $2.29 \%$ & $\begin{array}{l}4600 \\
0\end{array}$ & $2.02 \%$ & $66.36 \%$ \\
\hline 2 & Earthworks & $\begin{array}{l}40440 \\
15.10\end{array}$ & $\begin{array}{l}15.54 \\
\%\end{array}$ & $\begin{array}{l}2764 \\
645\end{array}$ & $\begin{array}{l}10.63 \\
\%\end{array}$ & $\begin{array}{l}3863 \\
31.9 \\
5\end{array}$ & $1.48 \%$ & $\begin{array}{l}8810 \\
196 . \\
2\end{array}$ & $\begin{array}{l}33.86 \\
\%\end{array}$ & $\begin{array}{l}4575 \\
48.5 \\
9\end{array}$ & $1.76 \%$ & $63.27 \%$ \\
\hline 3 & $\begin{array}{ll}\text { Stone } & \text { masonry } \\
\text { works } & \end{array}$ & $\begin{array}{l}13690 \\
45.00\end{array}$ & $1.87 \%$ & $\begin{array}{l}1257 \\
0596\end{array}$ & $\begin{array}{l}17.21 \\
\%\end{array}$ & $\begin{array}{l}1047 \\
4538\end{array}$ & $\begin{array}{l}14.34 \\
\%\end{array}$ & $\begin{array}{l}2417 \\
056 . \\
5\end{array}$ & $3.31 \%$ & $\begin{array}{l}2401 \\
1100\end{array}$ & $\begin{array}{l}32.88 \\
\%\end{array}$ & $69.62 \%$ \\
\hline 4 & Gabion works & $\begin{array}{l}44150 \\
0.00\end{array}$ & $1.01 \%$ & $\begin{array}{l}6525 \\
000\end{array}$ & $\begin{array}{l}14.88 \\
\%\end{array}$ & $\begin{array}{l}3863 \\
250\end{array}$ & $8.81 \%$ & $\begin{array}{l}3147 \\
750\end{array}$ & $7.18 \%$ & $\begin{array}{l}5541 \\
750\end{array}$ & $\begin{array}{l}12.64 \\
\%\end{array}$ & $44.51 \%$ \\
\hline 5 & $\begin{array}{l}\text { Formworks and } \\
\text { Concrete works }\end{array}$ & $\begin{array}{l}93865 \\
.00\end{array}$ & $0.17 \%$ & $\begin{array}{l}4371 \\
40\end{array}$ & $\begin{array}{l}0.79 \\
\%\end{array}$ & $\begin{array}{l}5040 \\
20 \\
\end{array}$ & $0.91 \%$ & $\begin{array}{l}1332 \\
10\end{array}$ & $0.24 \%$ & $\begin{array}{l}9364 \\
30\end{array}$ & $1.70 \%$ & $3.82 \%$ \\
\hline 6 & $\begin{array}{l}\text { Subbase,Base and } \\
\text { shoulder works }\end{array}$ & 0.00 & $0.00 \%$ & 0 & $\begin{array}{l}0.00 \\
\%\end{array}$ & 0 & $0.00 \%$ & 0 & $0.00 \%$ & 0 & $0.00 \%$ & $0.00 \%$ \\
\hline 7 & Misc works & $\begin{array}{l}90000 \\
.00\end{array}$ & $1.02 \%$ & $\begin{array}{l}7400 \\
00\end{array}$ & $\begin{array}{l}8.41 \\
\%\end{array}$ & $\begin{array}{l}4500 \\
00\end{array}$ & $5.12 \%$ & 0 & $0.00 \%$ & $\begin{array}{l}1590 \\
000\end{array}$ & $\begin{array}{l}18.07 \\
\%\end{array}$ & $32.62 \%$ \\
\hline
\end{tabular}


DOI: 10.5281/zenodo.2580485

\begin{tabular}{|l|l|l|l|l|l|l|l|l|l|l|l|l|}
\hline 8 & $\begin{array}{l}\text { Bio Engineering } \\
\text { works }\end{array}$ & 0.00 & $0.00 \%$ & 0 & $\begin{array}{l}0.00 \\
\%\end{array}$ & 0 & $0.00 \%$ & 0 & $0.00 \%$ & 0 & $0.00 \%$ & $0.00 \%$ \\
\hline & Total Amount & $\begin{array}{l}72917 \\
25.10\end{array}$ & $\begin{array}{l}74.74 \\
\%\end{array}$ & $\begin{array}{l}2313 \\
7381\end{array}$ & $\begin{array}{l}56.32 \\
\%\end{array}$ & $\begin{array}{l}1573 \\
5639\end{array}$ & $\begin{array}{l}33.20 \\
\%\end{array}$ & $\begin{array}{l}1456 \\
0213\end{array}$ & $46.9 \%$ & $\begin{array}{l}3258 \\
2829\end{array}$ & $\begin{array}{l}69.07 \\
\%\end{array}$ & \\
\hline & Average Progress & & $9.34 \%$ & & $\begin{array}{l}7.04 \\
\%\end{array}$ & & $4.15 \%$ & & $5.86 \%$ & & $8.63 \%$ & \\
\hline & $\begin{array}{l}\text { Total Cumulative } \\
\text { Progress }\end{array}$ & & $9.34 \%$ & & $\begin{array}{l}16.38 \\
\%\end{array}$ & & $\begin{array}{l}20.53 \\
\%\end{array}$ & & $\begin{array}{l}26.39 \\
\%\end{array}$ & & $\begin{array}{l}35.03 \\
\%\end{array}$ \\
\hline
\end{tabular}

(From Annex III)

The actual progress of project was analyzed by studying the different Interim payment documents of the project. The table 4.3 shows the phases of project. The completion $\%$ of different items is calculated based on payment made till the respective dates. it revels with results of Mishra and Bhandari (2018).

By table 4.3, it can be analyzed that, activity lying in the critical path, General Works and site clearance work is completed only by $66.36 \%$ till the originally intended completion date i.e. 22 Dec, 2017. Another critical activity Sub-base, Base and shoulder work is still not started till the date. So, it can be clearly seen, the project is under chronic situation having time overrun. Studying the Time extension document, now, the time extension of 241 days from completion date is proposed from district unit upon request of contractor showing various constraining factor which has caused delay. It is similar to Mishra et.al. (2018).

The respective S-curve of proposed schedule of project and actual progress is shown in fig 4.2

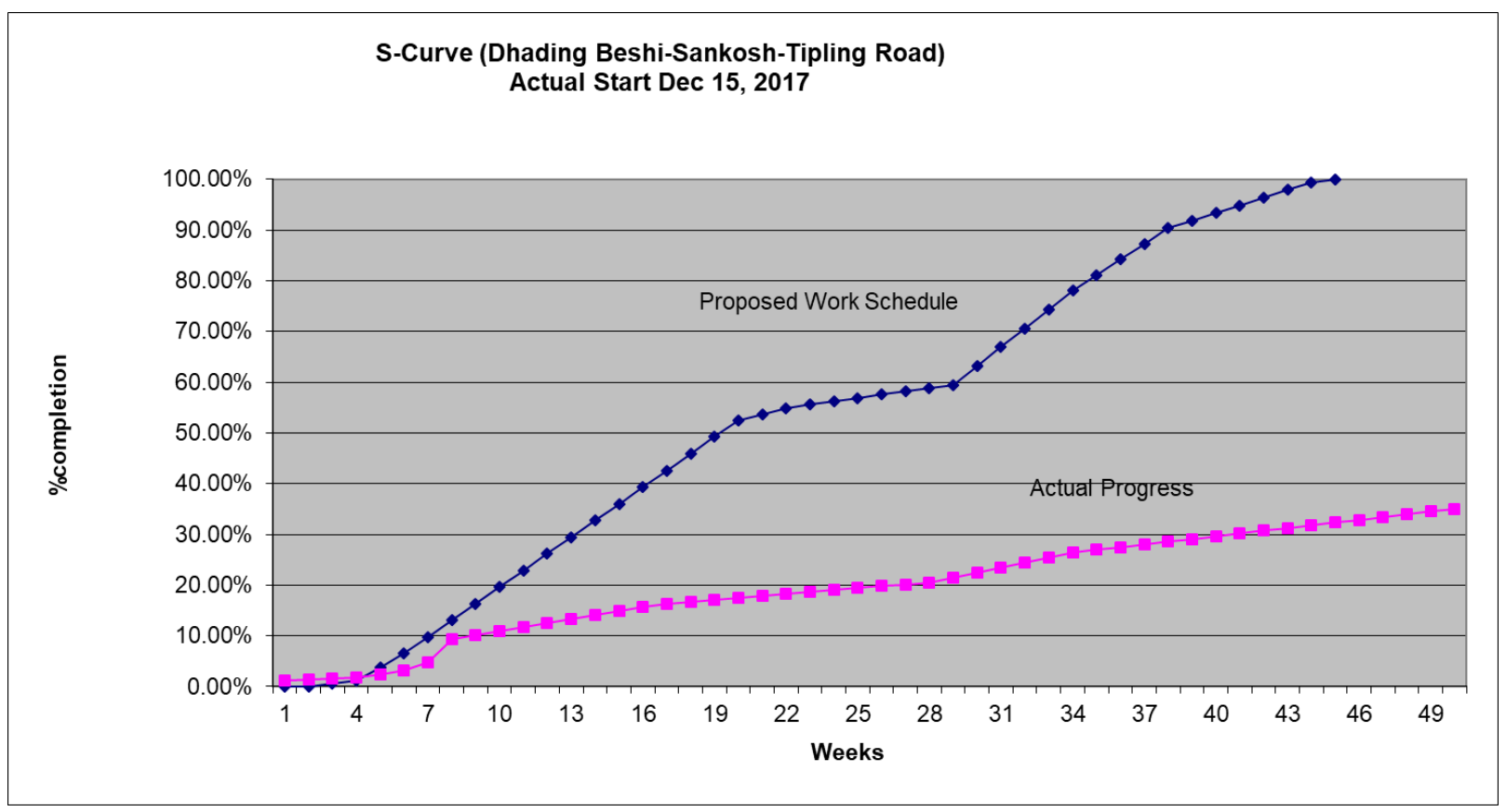

Figure 4.2: S-curve of Schedule (Sankosh-Tipling)

\section{Constraint of "Bhimdhunga-Lamidanda Road Dhading"}

This study was carried out to apply the five focusing steps of the Theory of Constraint (TOC). This study was targeted to crash the project schedule by applying the Theory of Constraints (TOC). 
The proposed Schedule of Project (From Annex IV)

\begin{tabular}{|c|c|c|c|c|c|c|c|c|c|c|c|c|c|c|c|c|c|}
\hline \multirow{2}{*}{ S.N } & \multirow{2}{*}{$\begin{array}{c}\text { Description of } \\
\text { Work }\end{array}$} & \multicolumn{12}{|c|}{2016} & \multicolumn{3}{|c|}{2017} & \multirow{2}{*}{ Remarks } \\
\hline & & Jan & $\mathrm{Feb}$ & Mar & Apr & May & Jun & Jul & Aug & Sept & Oct & Nov & Dec & Jan & $\mathrm{Feb}$ & Mar & \\
\hline 1 & Site Mobilization & & & & & & & & & & & & & & & & \\
\hline 2 & Site Survey & & & & & & & & & & & & & & & & \\
\hline 3 & $\begin{array}{l}\text { Man Power } \\
\text { Managem ent }\end{array}$ & & & & & & & & & & & & & & & & \\
\hline 4 & $\begin{array}{l}\text { Construction of } \\
\text { Labor Camp }\end{array}$ & & & & & & & & & & & & & & & & \\
\hline 5 & Site Clearance & & & & & & & & & & & & & & & & \\
\hline 6 & $\begin{array}{l}\text { Earthw ork in } \\
\text { ex cavation for road } \\
\text { works and drain }\end{array}$ & & & & & & & & & & & & & & & & \\
\hline 7 & $\begin{array}{l}\text { Preparation of Sub- } \\
\text { grade, subbase and } \\
\text { base course }\end{array}$ & & & & & & & & & & & & & & & & \\
\hline 8 & $\begin{array}{l}\text { Construction of } \\
\text { Bituminious work }\end{array}$ & & & & & & & & & & & & & & & & \\
\hline 9 & $\begin{array}{c}\text { Stone Masonry } \\
\text { works }\end{array}$ & & & & & & & & & & & & & & & & \\
\hline 10 & $\begin{array}{c}\text { Gabion Masonry } \\
\text { w orks }\end{array}$ & & & & & & & & & & & & & & & & \\
\hline 11 & $\begin{array}{l}\mathrm{RCC} / \mathrm{PCC}, \\
\text { formworks }\end{array}$ & & & & & & & & & & & & & & & & \\
\hline 12 & Bio-Engineering & & & & & & & & & & & & & & & & \\
\hline 13 & Miscellaneous & & & & & & & & & & & & & & & & \\
\hline
\end{tabular}

Figure 4.3: Proposed Work Schedule (Bhimdhunga-Lamidada)

The bar chart shows the proposed work schedule submitted at the time of agreement. Schedule consist of various work discipline such as Site survey, Site clearance, Earthwork, preparation of sub-grade, sub-base, base and shoulder, Bituminous work, Stone masonry work, Gabion works, PCC/RCC, formworks, Bio-Engineering and Miscellaneous works. The major work items are identified as Earthwork, sub-grade, sub-base and base course preparation, bituminous work, stone masonry and gabion work.

The actual implementation time of work is extended for two times. The first-time extension was done on May 8, 2017 for 124 days with completion date September 21, 2017 and 2nd time extension was done on January 14, 2018 for 185 days with completion date March 25, 2018. Referring to Annex V, it can be analyzed that, the project has excessive time overrun. The reason behind the constraint of the work processes are as follows.

1) Scarcity of Fuel due to political Hindrances

2) Unseasonal Rainfall 
3) Local Election in Province No.3

4) Social issues leading to local disturbances at site

5) Torrential rainfall consequently causing massive landslides at various chainage and management of clearance of slides

6) Restriction of District Coordination Committee (DCC) to collect gravel and boulders from river and quarry sites

7) Delay in Relocation of Services (Shifting of Electric Poles)

8) Central and Provincial Level Election

Studying the project reports, documents, these constraints were identified and verified thorough close consultation and questionnaire survey with project team, and it can be analyzed that the constraints for major work processes like Earthworks, Sub-grade, sub-base and base works are caused due to some social, environmental, political and legal problems which has caused excessive delay in agreed date of completion.

\section{Actual Progress of Project}

The actual progress of project based on project documentation is analyzed by studying the different Interim payment documents of the project. The following table 5.4 shows the phases of project. The completion \% of different items is calculated based on payment made till the respective dates.

Table 4.5Actual Progress of Project (Bhimdhunga-Lamidada) Project till Jun 13, 2017

\begin{tabular}{|c|c|c|c|c|c|c|c|c|c|}
\hline & & & 1st July & 2016 & 18th, $\mathrm{Fe}$ & 2017 & 13 june & 2017 & Item \\
\hline & $\begin{array}{l}\text { Description of } \\
\text { works }\end{array}$ & $\begin{array}{l}\text { BOQ } \\
\text { amoun } \\
t\end{array}$ & $\begin{array}{l}\text { Amou } \\
\text { nt }\end{array}$ & $\begin{array}{l}\text { \%comp } \\
\text { leted }\end{array}$ & $\begin{array}{l}\text { Amou } \\
\text { nt }\end{array}$ & $\begin{array}{l}\text { \% Comp } \\
\text { leted }\end{array}$ & $\begin{array}{l}\text { Amou } \\
\text { nt }\end{array}$ & $\begin{array}{l}\text { \% Comp } \\
\text { leted }\end{array}$ & $\begin{array}{l}\text { wise } \\
\text { Cumula } \\
\text { tive } \\
\text { \% compl } \\
\text { etion }\end{array}$ \\
\hline 1 & $\begin{array}{l}\text { General Works\& } \\
\text { Site clearance }\end{array}$ & $\begin{array}{l}166600 \\
0\end{array}$ & $\begin{array}{l}754333 \\
.33\end{array}$ & $45.28 \%$ & $\begin{array}{l}166666 \\
.67\end{array}$ & $10.00 \%$ & 80000 & $4.80 \%$ & $60.08 \%$ \\
\hline 2 & Earthworks & $\begin{array}{l}618331 \\
2\end{array}$ & $\begin{array}{l}368738 \\
0.00\end{array}$ & $59.63 \%$ & $\begin{array}{l}179413 \\
3\end{array}$ & $29.02 \%$ & $\begin{array}{l}96274 . \\
9\end{array}$ & $1.56 \%$ & $90.21 \%$ \\
\hline 3 & $\begin{array}{l}\text { Sub-base,Base and } \\
\text { Shoulders }\end{array}$ & $\begin{array}{l}210175 \\
72.5\end{array}$ & 0.00 & $0.00 \%$ & 0 & $0.00 \%$ & 0 & $0.00 \%$ & $0.00 \%$ \\
\hline 4 & Bituminious works & $\begin{array}{l}196473 \\
00\end{array}$ & 0.00 & $0.00 \%$ & 0 & $0.00 \%$ & 0 & $0.00 \%$ & $0.00 \%$ \\
\hline 5 & $\begin{array}{l}\text { Stone } \\
\text { Works }\end{array}$ & $\begin{array}{l}204046 \\
02.6\end{array}$ & 0.00 & $0.00 \%$ & $\begin{array}{l}101511 \\
22.6\end{array}$ & $49.75 \%$ & $\begin{array}{l}307657 \\
8.15\end{array}$ & $15.08 \%$ & $64.83 \%$ \\
\hline 6 & Gabion Works & $\begin{array}{l}723625 \\
0\end{array}$ & 0.00 & $0.00 \%$ & $\begin{array}{l}358225 \\
0\end{array}$ & $49.50 \%$ & 838250 & $11.58 \%$ & $61.09 \%$ \\
\hline 7 & $\begin{array}{ll}\text { PCC, } & \text { RCC\& } \\
\text { Formworks } & \\
\end{array}$ & $\begin{array}{l}140917 \\
54.2 \\
\end{array}$ & 0.00 & $0.00 \%$ & 393200 & $2.79 \%$ & $\begin{array}{l}132003 \\
.8 \\
\end{array}$ & $0.94 \%$ & $3.73 \%$ \\
\hline 8 & $\begin{array}{ll}\text { Bio } & \text { Engineering } \\
\text { works } & \\
\end{array}$ & 307500 & 0.00 & $0.00 \%$ & 0 & $0.00 \%$ & 0 & $0.00 \%$ & $0.00 \%$ \\
\hline 9 & $\begin{array}{l}\text { Miscellaneous } \\
\text { Works }\end{array}$ & $\begin{array}{l}257045 \\
5\end{array}$ & 0.00 & $0.00 \%$ & 650000 & $25.29 \%$ & 195000 & $7.59 \%$ & $32.87 \%$ \\
\hline & Total & $\begin{array}{l}931247 \\
46.3\end{array}$ & $\begin{array}{l}444171 \\
3.33\end{array}$ & $\begin{array}{l}104.91 \\
\%\end{array}$ & & $166 \%$ & & $42 \%$ & \\
\hline & Actual Progress & & & $11.66 \%$ & & $18.48 \%$ & & $4.62 \%$ & \\
\hline & Actual Cumulative & & & $11.66 \%$ & & $30.14 \%$ & & $34.76 \%$ & \\
\hline
\end{tabular}


By the progress Table 4.4 of the work activities, it can be analyzed that major work process Earthwork is completed only $29 \%$, stone masonry work 50\%, Gabion works 50\%, \& Sub-base, Base/Shoulder and Bituminous works are not started till the previously agreed date of completion. Then time was extended for 124 days for the first time with intention of completing all works within this period. But, it can be clearly seen that, the major work processes Sub-base, Base/Shoulder and Bituminous works are not started till 13 June, 2017.

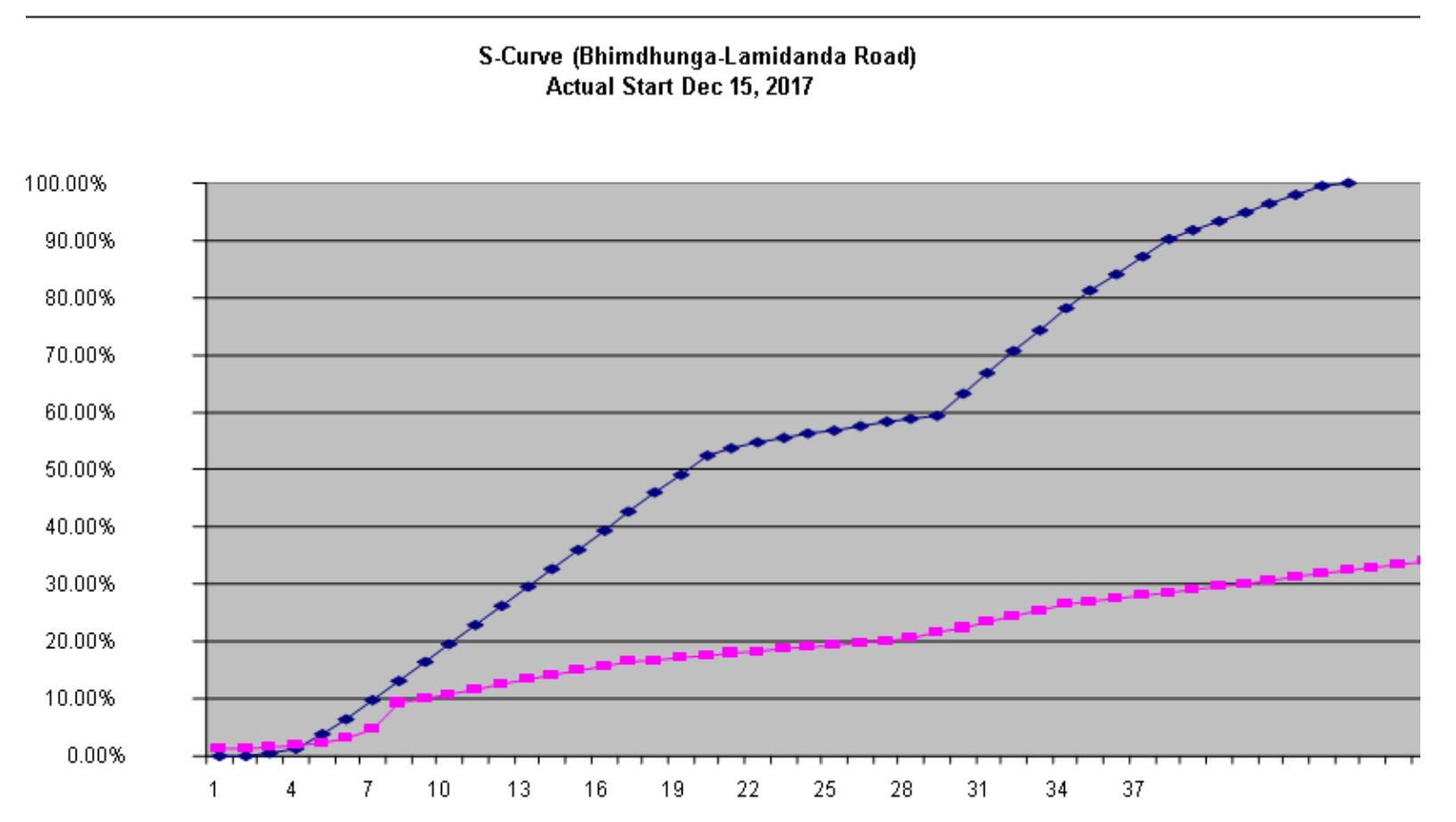

The respective S-curve of proposed schedule of project and actual progress is shown in fig 4.4 Figure 4.4: S-curve showing work schedule (Bhimdhunga-Lamidada)

\section{Conclusion}

The Conclusion of this study can be summarized as follows: -

- Study was carried out to identify the major constraints in the road project.

In this study of Sakosh-Tipling Road Project, the constraint as a technical constraint i.e. change in design and survey report was found as major constraint of the project schedule. The critical path itself is a constraint to the work schedule, thus critical activities like mobilization and joint survey, General works and site clearance, sub-base, base and shoulder works were the identified constraint in the project schedule. It has been found that activities lying in the critical path are completed only by $66.36 \%$ and the overall progress of the project was only by $35 \%$ till its previously agreed date of completion (i.e. Dec, 2017). And it was preceded for 241 days of time extension.

Similarly, in this study of Bhimdhunga-Lamidanda Road Project, the constraint as legal constraint caused by restriction of District Coordination Committee (DCC) to collect gravel and boulders from river and quarry sites was identified as major constraint to cause delay. The activities lying on critical path such as major work process Earthwork is completed only $29 \%$, stone masonry 
work 50\%, Gabion works 50\%, \& Sub-base, Base/Shoulder and Bituminous works are not started and overall progress of the project was only by $34.76 \%$ till Jun, 2017, where previously agreed date of completion was April, 2017 and it has been proceeded for total 309 days of time extension.

\section{References}

[1] Bushong, G., \& Talbott, J. C. (1999). The CPA in the industry, An application of Theory of Constraints. The CPA journal.

[2] Chua, D. K., J, S. L., \& BOK, S. H. (2003). Constraint-based planning with integrated production schedule over internet. Journal of Engineering and Management, 129 (3).

[3] Jacob, D. B., \& William T. McClleland, J. (2001). Theory of Constraints Project Managment: A brief introduction into the basics. Retrieved 7 24, 2017, from

http://www.public.navy.mil/airfor/nae/AIRSpeed\%20Documents/TOC\%20and\%20Project\%20M anagement.pdf

[4] Lau, E., \& Kong, J. J. (2006). Identification of Constraints in Construction Projects to Improve Performance. Retrieved 7 24, 2017, from https://www.irbnet.de/daten/iconda/CIB4451.pdf

[5] Raz, T., Barnes, R., \& Dvir, D. (2003). A Critical Look at Critical Chain Project Management. Project Managemnet Journal, 34 (4), 24-32.

[6] Mishra.A.K., Mallik.K. Factors and Impact of Risk Management Practice on success of Construction Projects of Housing Developers, Kathmandu, Nepal. International Journal of Sciences: Basic and Applied Research (IJSBAR) (2017) Volume 36, No 7, pp 206-232.

[7] Mishra.A.K. Implementation Status of Value Management in Project Management Practice in Nepal. International Journal of Management Studies. Vol.-VI, Issue -1(1), January2019.

[8] Mishra AK. Assessment of Human Resource Capacity of Construction Companies in Nepal. J Adv Res Jour Mass Comm 2018; 5(4): 14-25.

[9] Mishra AK, Bhandari S, Jha T. Factors Affecting Performance and Time Extension of ongoing Construction Projects under Town Development Fund, Nepal. J Adv Res Const Urban Arch 2018; 3(4): 7-25

[10] Mishra AK, Bhandari S. Performance Assessment of Ongoing Construction Projects under Town Development Fund, Nepal, Int j Adv Res Civil Stru Engr 2018; 1(1\&2): 27-39.

[11] Stratton, R. (2010). Critical Chain Project Management Theory and Practice. Retrieved 6 22, 2017, from https://www4.ntu.ac.uk/nbs/document_uploads/94592.pdf

[12] Stratton, R., Koskela, L., \& Alsehaimi, A. (2010). Applying Manufacturing Flow Theory to Construction Management. Retrieved 7 25, 2017, from http://tocpractice.com/wiki/2015/11/27/chapter-7-applying-manufacturing-flow-theory-toconstruction-management-stratton-koskela-alsehaimi-and-koskenvesa/

[13] Victoria_University. (2016). Theory of Constraint: A research Database. Retrieved from https://www.victoria.ac.nz/som/research/theory-of-constraints

[14] Vorne_Industry. (2011). Combining Theory of Constraints and Lean Manufacturing. Retrieved 7 20, 2017, from https://www.leanproduction.com/theory-of-constraints.html

[15] Walker, A. (1989). Project management in construction (6th ed.). Wiley Blackwell.

*Corresponding author.

E-mail address: anjaymishra2000@ gmail.com 